\title{
NTS Gene Product
}

National Cancer Institute

\section{Source}

National Cancer Institute. NTS Gene Product. NCI Thesaurus. Code C126487.

A protein encoded by the NTS gene. 